\title{
POPULATION CHANGES IN WATER- ASSOCIATED BIRDS AT BESNARD LAKE, SK, 1976-2005
}

JON M. GERRARD, P. NAOMI GERRARD, 119 Brock St., Winnipeg, MB R3N 0Y5, ELSTON H. DZUS, Box 2347, Athabasca, AB T9S 2B8, GARY R. BORTOLOTTI, Dept. of Biology, University of Saskatchewan, 112 Science PI., Saskatoon, SK S7K 5E2 and EMILY SCRAGG, Brook House, Pennington, Nr Ulverston, Cumbria, LA12 0JW, England.

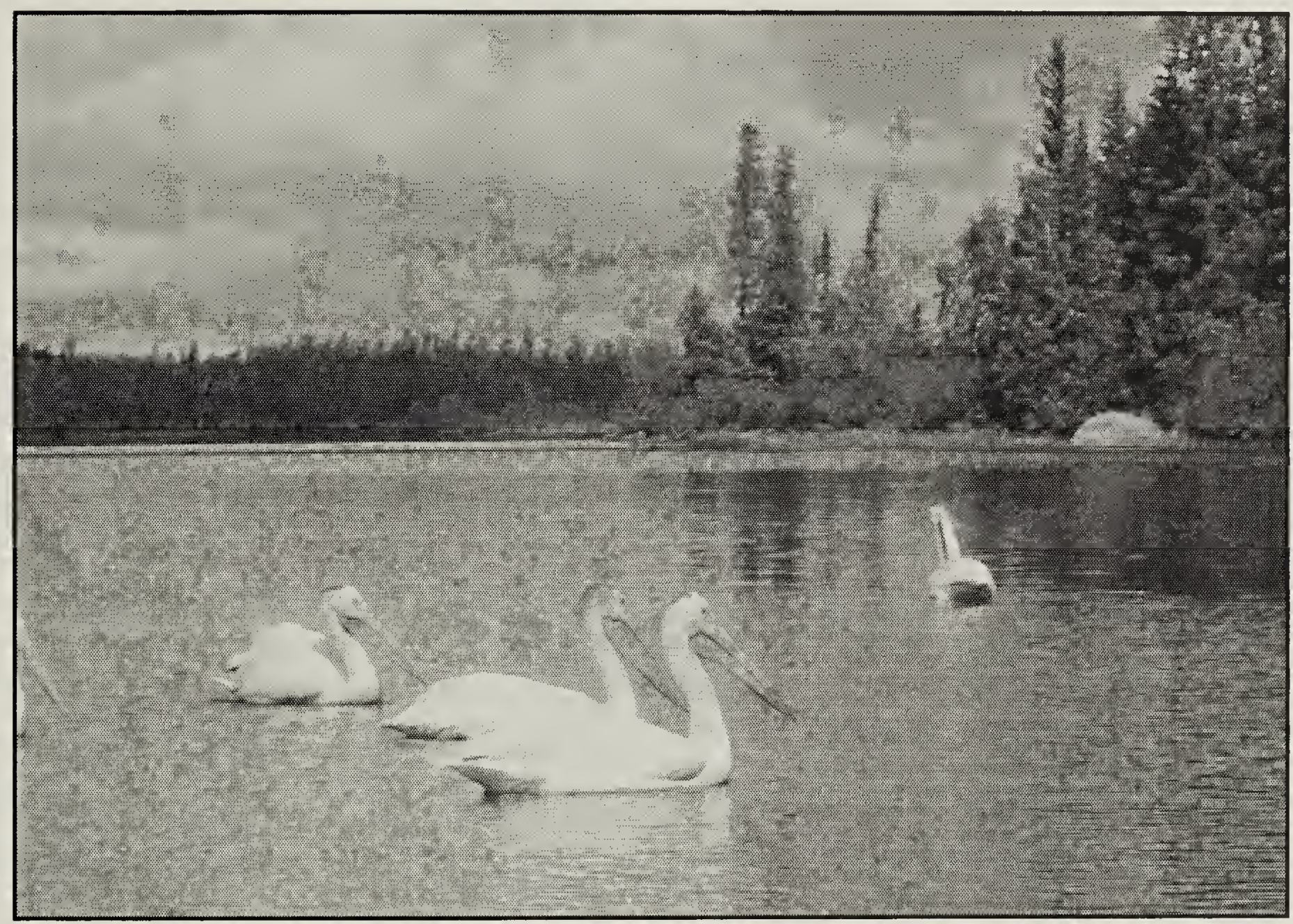

\section{Introduction}

Spatial and temporal variations in animal populations can result from changes in the amount of suitable habitat, food availability or human disturbance. ${ }^{8}$ As one example, differences in Bald Eagle populations on Besnard and Nemeiben Lakes were due primarily to corresponding differences in prey (fish) populations. ${ }^{2}$ Tracking changes in bird populations can be useful in understanding changes in prey availability and habitat quality as well as in the birds themselves. It is in this context that we report results of boat surveys on Besnard Lake in 2003, 2004 and 2005, and compare the findings with observations made from 1976 to 1990.

Besnard Lake, about $50 \mathrm{~km}$ west of La Ronge, SK and just south of the Churchill River, is on the southern boundary of the Precambrian Shield 
and within the boreal forest. It falls within the Churchill River drainage system. With a maximum length of 45 $\mathrm{km}$, Besnard Lake has some 255 islands, a water area of $177 \mathrm{~km}^{2}$, and a shoreline length of approximately 400 $\mathrm{km} .{ }^{3}$ The lake has two fishing camps, the first present before 1968, and the second established in 1973. There is also a campground with a boat ramp and dock which was built in the mid1970s. The road into Besnard Lake was completed in 1973, and resulted in increased sport fishing pressure. There are 68 recreational cabin leases on the lake, with a minimum distance of $1.6 \mathrm{~km}$ between cabins. Most cabins were built between 1972 and 1985, with a few built since 1995 .

\section{Methods}

The surveys described here were conducted from a small motor boat. For the purpose of these surveys, the shoreline was marked off into $8 \mathrm{~km}$ sections. Each survey (ideally two are done per summer, one in early July and one in late July) covered half of the shoreline by focusing on either the oddnumbered or even-numbered $8-\mathrm{km}$ long sections. One or more (usually three) observers in the boat travelled at $8-16 \mathrm{~km} / \mathrm{hr}$ between 20 and 100 meters from shore as described previously. ${ }^{4,5}$ For Bald Eagles, the survey was validated with an alternative approach to estimating the eagle population, using re-sightings of marked birds. ${ }^{7}$ In 2003 and 2005, odd numbered sections were covered during the first half of July, while in 2004, even numbered sections were censussed during this period. The findings for these years were compared with earlier surveys in the first half of July conducted in 1976 (odd sections), 1977 (odd sections), 1979 (even sections), 1984 (odd sections), and 1990 (odd sections).
Of the birds reported here, surveys in the first half of July in 1976 and 1977 included only Bald Eagles, Osprey and Common Loons. The remaining surveys included all species reported. Where three surveys of a species were conducted between 1976 and 1979, or between 2003 and 2005, the results are presented in the tables as the mean of the three surveys with the $95 \%$ confidence interval shown in brackets.

In these surveys, we did not include nestlings and we excluded young born in the year of the survey. Fledged Belted Kingfisher and Spotted Sandpiper young were not distinguished from adults on these surveys, but the young of these species rarely fledge on Besnard Lake until the last half of July, making it unlikely they contributed to the counts reported.

\section{Results}

Birds showing increases from 1976 to 2005

Birds showing increases from 1976 to 2005 are listed in Table I. For seven species, the number of birds observed on surveys between 1976-1990 was below the lower $95 \%$ confidence interval for the number of birds present in 2003-2005, indicating an increase in the bird population. For American White Pelican, the greatest increase occurred from 1979 to 1984 . Since 1984, their numbers have been reasonably stable. For mergansers (Red-breasted and Common mergansers were combined), there has been a progressive increase in numbers from 1979 to the present. For Common Goldeneye and Osprey, the increases occurred primarily between 1984 and 1990, with numbers showing less change from 1990 to 2005. For Bufflehead and Great Blue Heron, the biggest increases occurred between 1990 and 2003-2005. Ring-necked 


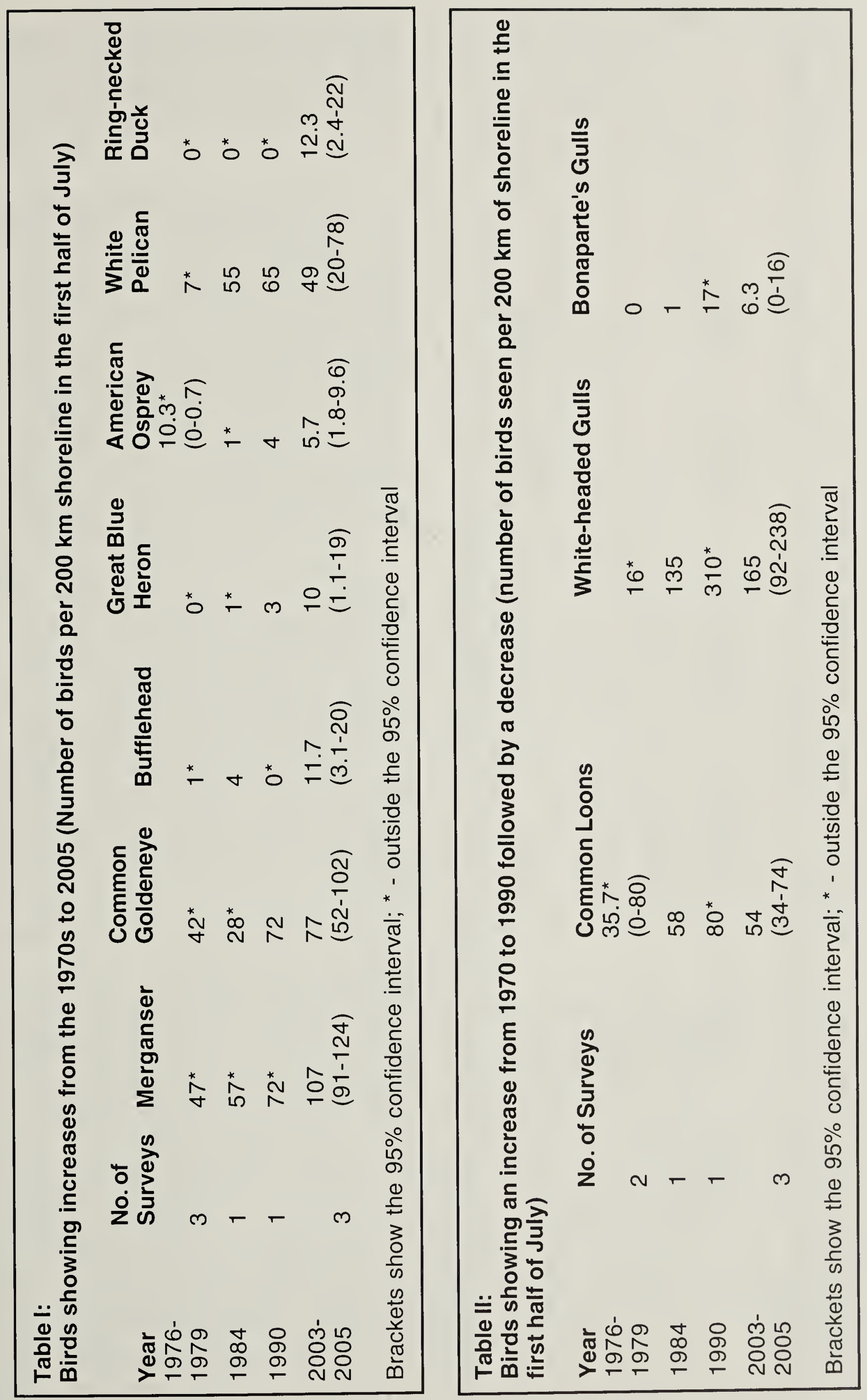




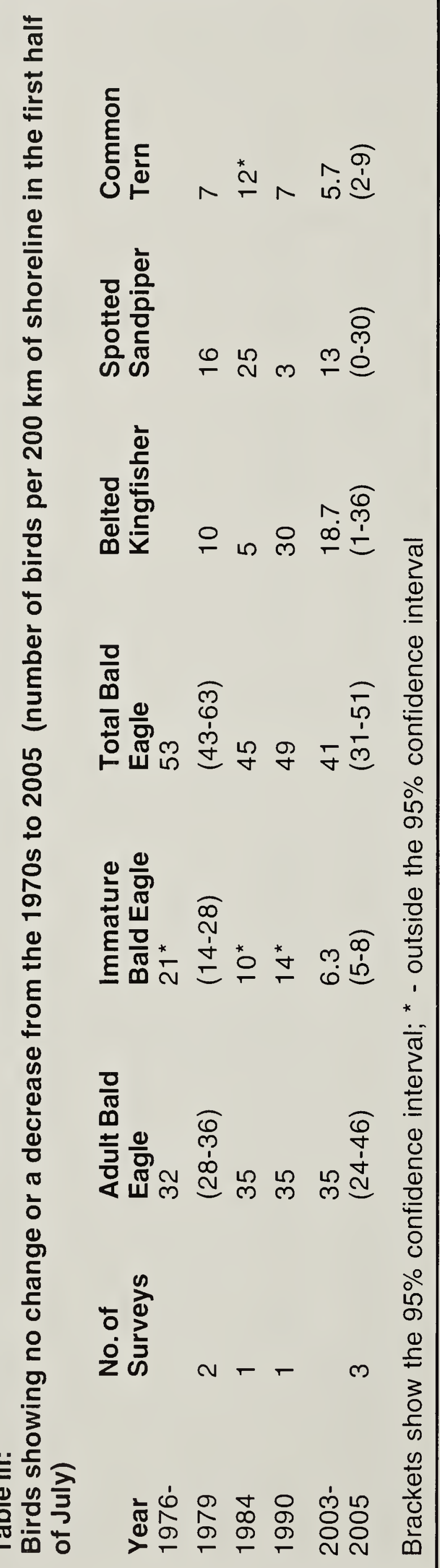

Ducks were present in 2003, 2004 and 2005, but from 1968 to 1990 were observed on Besnard Lake only twice in July - with pairs seen July 4 and 8, 1976.

For several species, we observed an increase in numbers in 2003-2005 compared to earlier years, but the variability of the results in 2003-2005 meant that the earlier results still fell within the $95 \%$ confidence interval for the population estimate for 2003-2005. For Mallards, five birds were seen in each of the 1976 and 1984 surveys, increasing to 24 in 1990 and an average of 23 from 2003-2005. Double-crested Cormorants were not seen on the lake in 1979 or 1984 , but were seen on surveys in 1990 (6 birds), with an average of 3.7 birds for 2003-2005. Canada Geese were present in early July in 2003 (one bird) and 2004 (two birds), but not previously on the surveys though we have made occasional previous observations of these geese in summer at other times. ${ }^{2}$ No Rednecked Grebes were seen on the 1979, 1984 or 1990 surveys, while these birds were seen in 2003 (12), 2004 (16) and 2005 (6).

\section{Birds showing an increase up to 1990} followed by a decrease

Species that increased from 1976 to 1990 , and then subsequently showed a decline, include the Bonaparte's Gull, white-headed gulls (Herring, California and Ring-billed gulls combined), and Common Loons (Table II). The decrease in numbers of the whiteheaded gulls from 1990 to 2003-2005 appears to be primarily in the number of Ring-billed Gulls. The number of Herring Gulls continued to be substantial from 2003-2005, indeed the majority of gulls which were identified in these recent years were Herring Gulls. This contrasts with 
earlier years when the Ring-billed Gulls were as common or more common than Herring Gulls. The proportion of California Gulls was relatively small on all surveys.

Birds showing no change or a possible decrease from the 1970s to 2004

The number of adult (with complete white head and tail) Bald Eagles on Besnard Lake has stayed stable from 1976 to 2005 (Table III). The number of immature Bald Eagles on Besnard Lake in early July has decreased since 1976. There was no significant change in the number of Belted Kingfishers, Spotted Sandpipers and Common Terns from 1976 to the present.

\section{Discussion}

The changes observed in numbers of birds on Besnard Lake from 1976 to 2005 are consistent with the postulate that increased fishing pressure removes larger predatory fish (walleye and northern pike), resulting in an increased availability of minnows and smaller fish ${ }^{6,10}$ and an increase in the species of birds for which smaller fish make up an important food source (mergansers, Great Blue Herons, American White Pelican and Osprey).

Increases in Common Goldeneye, Bufflehead and Red-necked Grebe might also reflect an increase in small fish, but for Common Goldeneye and Bufflehead, aquatic invertebrates are normally more important food sources, ${ }^{7,9}$ and the increase in these species could reflect an increase in aquatic invertebrates.

An alternative explanation is based on observations of increased algal growth around the shores of at least the southern parts of Besnard Lake starting in the late 1980 s and early 1990s. Algal growth on rocks was not present in the same way in the 1970s or early 1980s, and its presence now may indicate a change in the status of the lake toward being more eutrophic.

One of the noteworthy changes on Besnard Lake has been the increase in wild rice. Wild rice was seeded in certain shallow bays (particularly during the 1980s and early 1990s) and has since spread into other parts of the lake. On the 2003 and 2004 census, the Red-necked Grebes were associated with the wild rice habitat and we suspect the two are linked.

From 1976 to 1990 , fish offal from the fishing camps was put back into the lake waters and a landfill site for garbage was located within 0.3 kilometers of the lake. Between 1990 and 2003, the landfill site was moved to a new location a kilometer from the lake and fish offal was put in the landfill rather than in the lake. The increase in Ring-billed Gulls from the 1970s to 1990 and then the subsequent decrease may be related to the increased availability of offal and garbage to gulls from 1976 to 1990 , followed by a decrease from 1990 to 2005.

The modest decrease in Bald Eagles in 2004 and 2005 was related to fewer immatures seen on these surveys. Immatures normally move onto Besnard Lake from small lakes where numerous fish spawn in early July. It is possible this movement was delayed in the period from 2003 to 2005 so that immatures were seen in fewer numbers on these surveys. The number of breeding Bald Eagles has not changed significantly from 1976 to 2005. 
Acknowledgements: We thank Nikki Gerrard for her help with the surveys. Funding was provided, in part, from Nature Saskatchewan and the Stuart and Mary Houston Professorship in Ornithology of the University of Saskatchewan.

1. ARNASON, A. N., SCHWARZ, C. J. and GERRARD, J. M. 1991. Estimating closed population size and number of marked animals from sighting data. Journal of Wildlife Management 55:716-730.

2. DZUS, E. H. and GERRARD J. M. 1993. Factors influencing Bald Eagle densities in northcentral Saskatchewan. Journal of Wildlife Management57:771-778.

3.GERRARD, J. M., BORTOLOTTI, G. R. and WIEBE, K. L. 1996. Birds of the Besnard Lake Area, North-Central Saskatchewan 1968-1994. Special Publication No. 20, Saskatchewan Natural History Society, 1996.

4. GERRARD, J. M., BORTOLOTTI, G. R., DZUS, E. H., GERRARD, P. N., and WHITFIELD, D. W. A. 1990. Boat census of Bald Eagles during the breeding season. Wilson Bulletin 102:720-726.
5. GERRARD, J. M., DZUS, E. H., BORTOLOTTI, G. R., and GERRARD, P. N. 1993.Water-bird population changes in 1976-1990 on Besnard Lake, Saskatchewan: increases in loons, gulls and pelicans. Canadian Journal of Zoology 71:16811686.

6. HOBSON, K. A., KNAPTON, R.W., and LYSACK, W. 1989. Population, diet and reproductive success of Double-crested Cormorants breeding on Lake Winnipegosis, Manitoba in 1987. Colonial Waterbirds 12:191-197.

7. KORTRIGHT, F. H. 1942. The Ducks, Geese and Swans of North America. The Stackpole Company, Harrisburg, Pennsylvania.

8. NEWTON, I. 1979. Population Ecology of Raptors. Buteo Books, Vermillion, South Dakota.

9. POOLE, A and GILL, F (editors) 2002. The Birds of North America, Academy of Natural Sciences, Philadelphia, Pennsylvania.

10. SULLIVAN, M. 2003. Management of lowproductivity fish stocks: decline and collapse of Alberta's walleye fisheries. Ph.D. Thesis, University of Alberta.

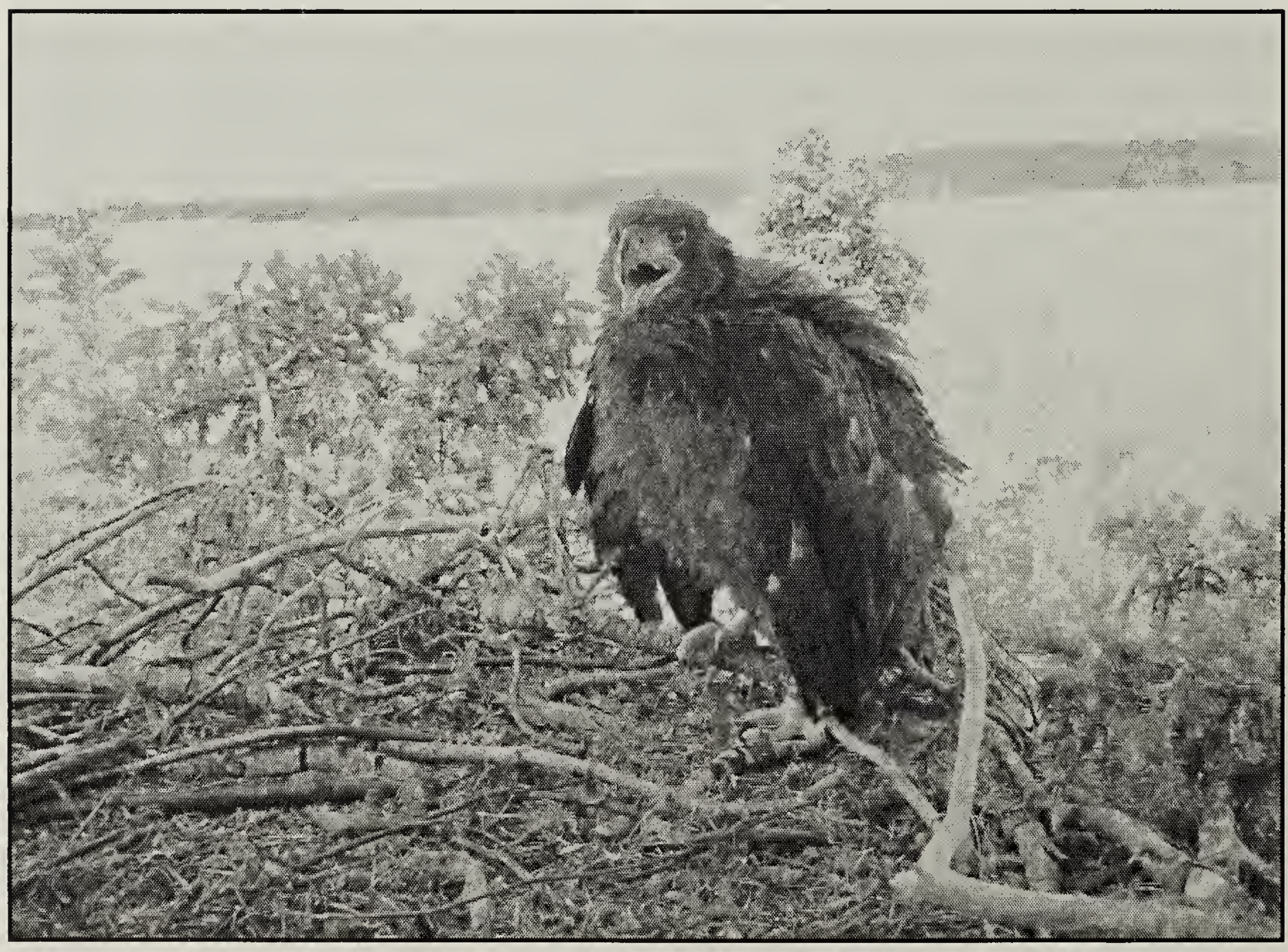

